Research, part of a Special Feature on Realizing Water Transitions: The Role of Policy Entrepreneurs in Water Policy Change

\title{
Implementing Integrated River Basin Management in China
}

\author{
Dorri G. J. te Boekhorst ${ }^{1}$, Toine J. M. Smits ${ }^{1}$, Xiubo Yu ${ }^{2}$, Lifeng Li $^{3}$, Gang Lei ${ }^{3}$, and Chen Zhang ${ }^{3}$
}

\begin{abstract}
This paper examines the role of the World Wildlife Fund for Nature China as policy entrepreneur in China. It illustrates the ways in which the World Wildlife Fund for Nature is active in promoting integrated river basin management in the Yangtze River basin and how the efforts at basin level are matched with the advice of the China Council for International Cooperation on Environment and Development task force on integrated river basin management to the national government of China. This article demonstrates that the World Wildlife Fund for Nature uses various strategies of different types to support a transition process towards integrated river basin management. Successful deployment of these strategies for change in environmental policy requires special skills, actions, and attitudes on the part of the policy entrepreneur, especially in China, where the government has a dominant role regarding water management and the position of policy entrepeneurs is delicate.
\end{abstract}

Key Words: China; integrated river basin management; policy entrepreneur; Yangtze River basin

\section{INTRODUCTION}

Water-related problems are one of the most pressing issues facing China. They are argued to have the potential ultimately to affect China's social, economic, and political stability. In terms of the sustainable development of the country, they could be an important limiting factor (Kreimer and Munasinghe 1991, World Bank 1997, Flavin and Gardner 2006, Turner and Otsuka 2006). The main challenges concerning water are threefold: water scarcity, water pollution, and flood control (Jones et al. 2003, Chen 2005, Lee 2006, Yin et al. 2006). To meet these challenges, China's river ecosystems have to be properly protected. This will involve the development of an alternative approach to water management and major changes in different areas of society from land use and government to livelihoods.

The new approach to water management is envisioned in the strategy of integrated river basin management (IRBM), which was incorporated into China's 2002 Water Law. In 2004, a major joint report by the World Wide Fund for Nature (WWF) and a task force of the China Council for
International Cooperation on Environment and Development (CCICED) stressed to the Chinese government the importance of IRBM (CCICED and WWF 2004). As a non-governmental organization (NGO), WWF China used its national and international network to stimulate the acceptance and application of IRBM. In this article, we focus on the role of WWF China as a policy entrepreneur. First, we present a general picture of the institutional setup and legislation related to water management in China. We then illustrate the strategy and activities of WWF China with two cases: the Central Yangtze: Partnership for a Living River and the WWF-HSBC Yangtze Programme. Finally, applying the concepts described in the paper of Huitema and Meijerink (2010), we analyze the role of WWF China as a policy entrepreneur.

WWF has been active in China since 1978 and has been able to develop successfully in Chinese society. The cases we present here productively link small-scale bottom-up processes with national topdown measures. The role of the CCICED IRBM Task Force as a high-level governmental advisory body is in part described using participatory observation by one of the Dutch authors of this 
chapter. All the Chinese authors are familiar with the cases presented here, either as former project leaders or as advisors on the process of integrating IRBM in China.

\section{Institutional framework}

The State Council of the People's Republic of China directs several ministries, agencies, and commissions involved in water management. The Ministry of Water Resources (MWR) manages all administration concerning water quantity in China. It is authorized by the Water Law to oversee China's water resource management. Its main responsibilities include surface and ground water management, river basin management, flood control, and water and soil conservation. Mediation and arbitration of intersector or inter-province water disputes are also part of the MWR responsibilities. The Ministry has water bureaus and departments at both the provincial and county levels (Turner and Otsuka 2006, MWR 2009).

One of the main laws and regulations providing the MWR mandate is the Water $\operatorname{Law}(1988$, revised 2002), the key legal instrument containing general principles for the management of water resources in China (Chen 2005, Lee 2006, OECD 2007). The Water Law (revised 2002) reflects current thinking on integrated water resource and demand management. It enshrines the principles that everyone should have access to safe water and that water conservation and environmental protection are governmental priorities. The law focuses on four topics: water allocation, rights and permits; river basin management; water use efficiency, and conservation and environmental protection. Furthermore, the law defines river basin management institutions and functions. One of its core goals is to strengthen the administrative rights of river basin management organizations in order to improve the implementation of water conservation and management measures. The law requires the integration of water resource and economic development planning (Turner and Otsuka 2006, OECD 2007). In addition to the Water Law, the Law on Prevention and Control of Water Pollution, the Water and Soil Conservation Law, and other relevant laws and regulations, such as the 1997 Flood Control Law, all support China's institutional framework for water policy.
The MWR is responsible for several other institutes and commissions that implement regulations regarding water resources management, of which the seven River Basin Commissions (RBCs) are the most important (Lee 2006, Yan et al. 2006, MWR 2009). The RBCs were originally created in the 1950 s to mitigate flood damage and exploit water resources, for instance, to generate electricity and provide navigation facilities. From a historical point of view, the RBCs are extensions of the MWR and are accustomed to taking a top-down, sectoral approach to river basin management (Turner and Otsuka 2005, 2006). This is slowly changing and is expected to change further while IRBM is being implemented in China.

In addition to the MWR, the Ministry of Environmental Protection (MEP)(upgraded in March 2008 from State Environmental Protection Agency to MEP), is another important ministry involved in monitoring and improving water quality and ecological rehabilitation of the fluvial ecosystem.

\section{Geohydrological data for the Yangtze River basin}

The Yangtze (Changjiang) River, at $6300 \mathrm{~km}$, is China's longest and the world's third longest river (Fig. 1). The snow-fed waterway starts in the Kunlun mountains of the Tibetan Plateau in Qinghai province, flows southeast, and empties into the East Chinese Sea about $20 \mathrm{~km}$ north of Shanghai. It has about 700 tributaries and is the largest river system in China with a basin covering an area close to $19 \%$ of China's total land area. It provides freshwater resources to around 400 million people (about a third of the Chinese population). The total water availability per year in the basin amounts to 996 billion $\mathrm{m}^{3}$ on a long-term mean basis $(36.5 \%$ of China's total). The basin area is rich in lakes, totaling an area of more than $15,200 \mathrm{~km}^{2}$, with most of them situated in the middle and lower reaches. The area includes the two largest freshwater lakes in China, Poyang Lake and Dongting Lake (CCICED and WWF 2004, Yang et al. 2007).

The Yangtze basin covers 19 provinces, autonomous regions, and municipalities. The river functions as the most important transportation network through the heart of some of the most densely populated and economically important 
Fig. 1. China and the Yangtze River basin, including Poyang Lake and Dongting Lake.

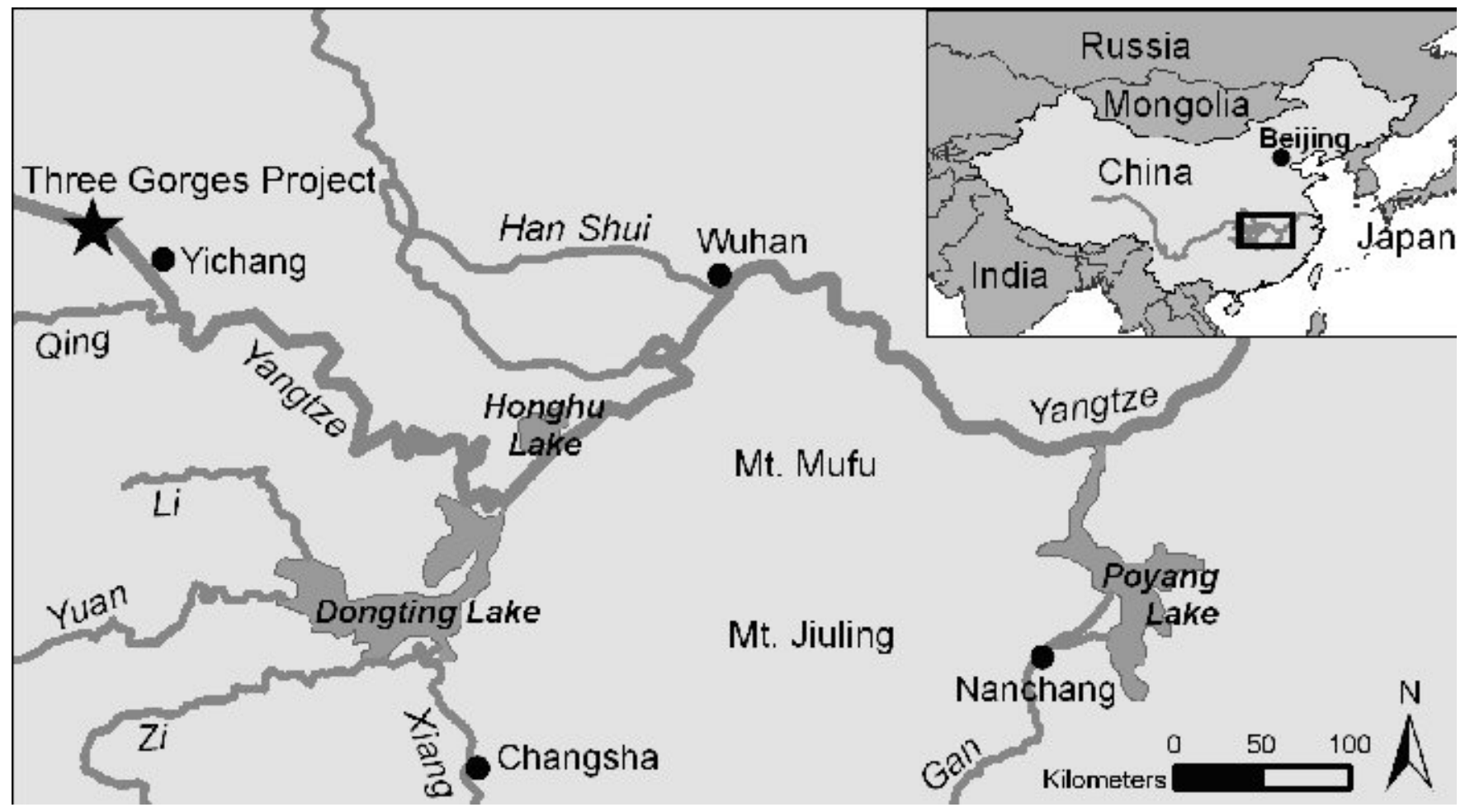

areas in China, known as the Yangtze River Economic Belt. The Yangtze is also the major inland navigation waterway with a navigation channel totaling $57,000 \mathrm{~km}$ (of which $2837 \mathrm{~km}$ is mainstream), $52.5 \%$ of the nation's total. The shipping capacity is equivalent to four to six railways, each of this same length (Changjiang Water Resources Commission (CWRC) 2009). The Yangtze is a major resource for irrigation, agriculture, and hydroelectric power (with a technically exploitable potential of 25,6270 MW and an estimated annual power output of more than $100 \mathrm{TWh}$, equivalent to $48 \%$ and $49 \%$, respectively, of the nation's totals). It currently holds 17 hydroelectric dams, including the well-known Three Gorges Dam. The Yangtze agricultural area delivers close to half the country's total crop harvest and contributes about a third of the national grain and GDP total. The river basin is recognized internationally as an important ecosystem that is rich in biodiversity (Yin et al. 2006), and currently, six wetlands are listed as sites under the Ramsar Convention on Wetlands of International
Importance (Cui and Wang 2008). Two-thirds of China's plant species occur in the basin. Three hundred and seventy fish species (several seriously threatened), and a diverse range of birds depend on the river basin system (CWRC 2009, WWF China 2009, WWF International 2009, Yangtze Forum 2009).

The Yangtze River basin is under the jurisdiction of the CWRC, one of the seven river basin commissions under the MWR. Together with the prefectural and local branches of the MEP, they are responsible for the water quality and quantity of the river basin. Other ministries under the State Council also have responsibilities related to management of the water system. Regional authorities (provinces, cities), and public and private organizations (e.g., conservation groups and construction firms) can be considered as "stakeholders" of the river basin given their various claims on land and water use and theirs views on management. 


\section{PROBLEM DEFINITION}

Unconstrained deforestation activities in the upstream parts of the river basin (Nakamura 2003) and gradual land reclamation activities in mid- and downstream sections (Zhao et al. 2003, Yin et al. 2006) have undermined the hydrological and ecological resilience of the river basin. Originally, Poyang Lake and Dongting Lake functioned as giant reservoirs that moderated extremes of high and low water discharges. However, during the past decades, especially between the 1930s and 1978, many of the natural lakes and wetlands have disappeared due to land reclamation. Moreover, hundreds of natural lakes, essential for spawning fish and the natural retention of water have been disconnected from the Yangtze River for agricultural purposes and to protect farmers and fishermen from waterborne diseases such as snail disease (schistosomiasis) (Fischer and Heilig 1997, Li et al. 2000, Utzinger et al. 2005). This has led to a dramatic decrease in the number of lakes, lake size, and flood retention areas (estimated decrease of $6000 \mathrm{~km}^{2}$ in surface area of lakes $\geq 1 \mathrm{~km}^{2}$ in Jianghan Plain alone) (Yin and Li 2001, Zhao and Fang 2004, Fang et al. 2006, Yin et al. 2006).

Aleviation of the structural water scarcity problems on the North China Plain (including the Haihe, Huaihe, and Huanghe River basins) by tapping into the relative abundance of water in the Yangtze River basin is seen as an important reason for moving forth with the South-to-North Water Transfer Project - a far reaching and enormous engineering project to divert water to the north through three planned routes: east, middle, and west (Varis and Vakkilainen 2001, Turner and Otsuka 2005, Yang and Zehnder 2005). Apart from water quantity related developments, pollution of the river system from industrial waste and mainly agricultural nonpoint sources provides the second serious threat to the river basin system (Wang et al. 2006). In general, water quality in China has deteriorated tremendously. The Yangtze River, on average, is considered relatively clean according to the 2007 State of the Environment report (in 2007, little over $80 \%$ of the sampling points were grade I-III, on a scale of I-V); however, locally and especially downstream water quality of the tributaries can be quite bad: grade IV or worse (MEP 2009). The relocation of large bodies of water to the North China Plain can put water quality in the Yangtze River basin under further pressure. Inhabitants rely on the basin for access to safe and clean drinking water. A decrease in water quality may negatively affect their access, and will also negatively affect the natural habitat of many species (Varis and Vakkilainen 2001, Fang et al. 2006).

\section{The shift to integrated river basin management}

It can be argued that many of the water problems in China result from an ongoing denial of the importance of a healthy ecosystem for a sustainable economy and from a sectoral approach to river basin management. Basically, the Five Year Plans were focused on the economic development of the country. With the start of the first one in 1953, economic growth was a top priority, and until the sixth Five Year Plan there was little attention given in these plans to environmental values. In addition, coordination was poor or non-existent among local and regional authorities within the river basin. Most administrators and politicians, and most of the general public considered the exploitation of the river and its catchment area as an undisputable right. Overarching problems were addressed by the MWR, but mainly from an engineering point of view. Hydraulic mission thinking (Waterbury 1979, Turton et al. 2007) has been the dominant paradigm in Chinese water management, as illustrated by the many vast hydro-engineering projects, including the present South-to-North Transfer Project.

However, recent years have seen an increased incidence of floods (major floods occurring every one and a half years between 1988 and 1998, instead of once every four to five years between 1852 and 1980), topped by the flood of 1998 and alarming environmental degradation entailing the loss of biodiversity and extinction of some endemic species (CCICED and WWF 2004, Zhao et al. 2005). These events, on top of existing problems, formed the motivation for the central government to change the situation (Zhao et al. 2006). The US\$1.2 billion " 32 character policy" (Fig. 2) was launched in 1998 by the central government after the recent flood events. Its aim was to stop further deterioration of the hydrological resilience of the Chinese river basins, and it can be interpreted as a first step towards IRBM.

Although the 32 character guiding policy was an important step in recognizing the key functions of nature in the sustainable use of a river basin, implementation at the local level has not been easy. Soon after the proclamation, its shortcomings 
Fig. 2. 32 character policy. The name refers to the number of Chinese characters needed to formulate the various policy measures.

\section{Stop logging and promote forestation (the National Logging Ban).}

\section{Stop agricultural use of mountain slopes and reintroduce forest and grass (Grain for Green).}

\section{Return reclaimed land to the river (make room} for the river).

\section{Convert cultivated land to wetlands and lakes (wetland restoration).}

5. Resettlement of people who live in flood prone areas.

6. Reinforce the primary flood defence structures.

7. Dredge river sections that have silted up.

8. Give people work instead of relief subsidies.

became clear. The policy does not properly address sustainable alternatives to "wrong" land use within the river basin (e.g., land reclamation for growing rice, extensive logging), and the many complex institutional arrangements between water resource management and land use plans have proven a real hindrance (Wang et al. 2007). Moreover, there was little or no awareness among the wider public of how a river (ecosystem) functions and of the urgent need for coordination of up- and downstream land use.

\section{WWF China as a policy entrepreneur for integrated river basin management}

Why is WWF so concerned with the fate of rivers? River basins are the way nature gathers and delivers water. They constitute ecosystems that provide services to humans in the form of hydropower, transportation, recreation, and tourism, as well as flood and drought regulation, sediment and nutrient retention, and habitat for diverse fauna and flora. Freshwater biodiversity is an important source of food, income and livelihood, particularly for rural communities in developing countries. Studies have estimated the economic value of "healthy" river basins in the billions of dollars (Costanza et al. 1997, Schuyt and Brander 2004, Schuyt 2005). Therefore, one of the primary goals of WWF is to develop 
strategies to manage the use of rivers and their wetlands without reducing biodiversity and ecological functioning (Jones et al. 2003).

To use and manage river basins in a sustainable way is complex, but in the experience of WWF (and others), no strategy will be effective unless it is implemented through cooperation across social, economic, and political boundaries (Muldavin 2000, Jones et al. 2003, Nakamura 2006). In this context, IRBM can be seen as a tool for communities to balance development and conservation needs. Hence, WWF's actions to support development and implementation of IRBM in China form part of such cooperation.

Against this background, WWFChina launched two major programs: The Central Yangtze: Partnership for a Living River, 1998-2008 (the Yangtze Focal Project builds upon this program), and the WWFHSBC Yangtze Programme in 2002. The Central Yangtze: Partnerships for a Living River program was started by WWF China in 1998. Initiative for this project came from WWF China, and the first financial donations to pay for related activities were generated by WWF Netherlands. Both programs supported the goal to "restore the Yangtze as a living river by securing effective management of a significant area of wetlands in the central Yangtze basin over a period of 25 years" (Jones et al. 2003). Realization of this goal requires cross-sectoral cooperation throughout the river basin, and public awareness and participation. IRBM was seen as an important tool in meeting this need and achieving the program aims (CCICED and WWF 2004). We describe two cases that illustrate the introduction of IRBM in China.

\section{The Central Yangtze: Partnership for a Living River}

This, in 2008 completed WWF program had the following objectives:

1. to restore Dongting Lake wetlands and to enhance the management of the Yangtze as a "living river" through partnership with all stakeholders; and

2. to restore biodiversity in the Central and Lower Yangtze River and develop new land use and flood plain management approaches with authorities and other organizations.
In order to realize these goals, pilot sites were selected to demonstrate that working through a bottom-up, co-production model, economic, ecological, and safety interests can be brought into harmony. Second, actions were taken to promote IRBM at the highest political level in order to facilitate the creation of a legal framework for organizing round table events for the stakeholders in the Central and Lower Yangtze regions (Hunan Province 2009, WWF, personal communication). Both sub-projects and the actions of the CCICED are discussed.

\section{Pilot sites: Dongting Lake}

Dongting Lake, China's second largest freshwater lake, is located in the southern part of the Central Yangtze River basin, in Hunan Province (Fig. 3). The lake area totals $15,465 \mathrm{~km}^{2}$ and spans 13 counties. The lake is one of the two remaining retention lakes that are naturally connected to the Yangtze River and is important in storing freshwater and reducing the extent and impact of flooding in areas occupied by people. Rich in biodiversity, including important fish and water bird populations and many threatened species (Fang et al. 2006), the lake is of great socio-economic and cultural importance. The Yangtze River and the lakes of its basin, including Poyang Lake and Dongting Lake, are listed by WWF as one of 200 global conservation priority regions (Olson and Dinerstein 1998).

Due to land reclamation, the size of the lake has been drastically reduced over the last few decades. The maximal lake area is set at the 1825 figure of $6270 \mathrm{~km}^{2}$. By the $1950 \mathrm{~s}$, this area had been reduced to $4350 \mathrm{~km}^{2}$, while the following 50 years saw yet another $1650 \mathrm{~km}^{2}$ reclaimed, shrinking the lake by an additional $40 \%$. Besides reduction, the lake also faces fragmentation (Zhao et al. 2005). To create and sustain the resulting "polder society" requires technical engineering in the form of dams, dykes, canals, and sluices. Such development weakens the lake's ability to store and safely release floodwaters. The natural siltation of the area adds slightly to this problem but is likely to decrease since the Three Gorges Dam will trap a large portion of the sediment (CCICED and WWF 2004, Schuyt 2005, Zhao et al. 2005).

Dongting Lake is divided into three sections: east (Dong), west (Xi), and south (Nan). East Dongting was one of the first seven sites to be designated in 1992 as the most important international wetland 
Fig. 3. Shrinkage of the Dongting Lake area due to land reclamation projects.

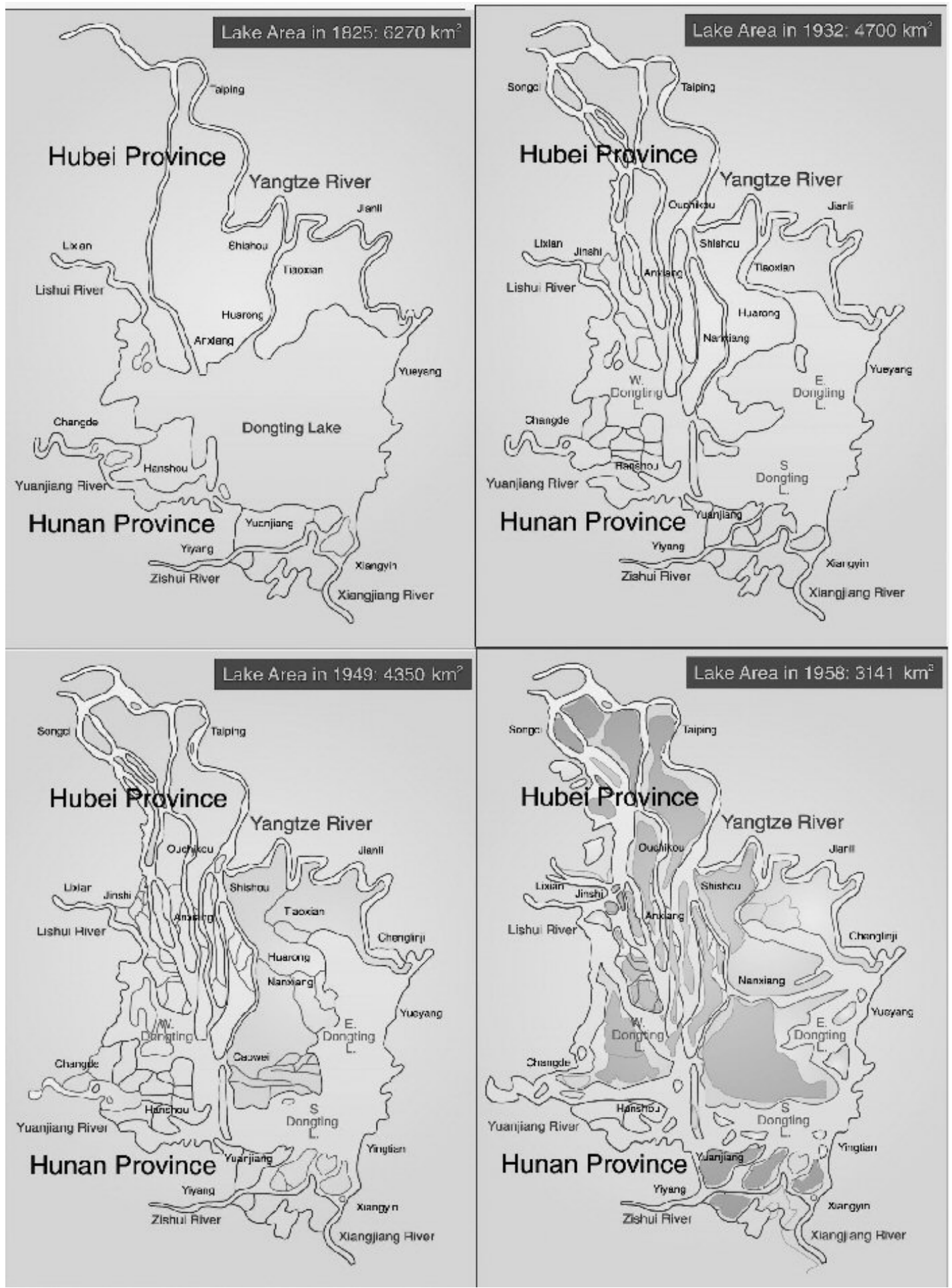


conservation areas in China under Ramsar (Ramsar Convention on Wetlands (Secretariat) 2009). In 2002, as a result of the WWF project, the State Forest Administration added south Dongting Wetland and Waterfowl Reserve and West Dongting Lake to the Ramsar list. The WWF project embarked on its specific aim to restore Lake Dongting and its wetlands in 10 years to their 1950 s maximal extent in order to reverse a massive loss of biodiversity and to improve ecological conditions and security for the conservation of the natural heritage, ecosystem, and species of the Yangtze (this proved to be too ambitious and was adjusted in 1992 to the more general goal of "restoring Dongting Lake wetlands"). This goal was combined with the aim of identifying alternative livelihoods for the local people that achieve a better balance with the natural environment (e.g., ecotourism). Improved security was the subject of the second specific objective for the lake, setting out wetland restoration as a means to mitigate catastrophic peak floods that destroy economic, agricultural, and infrastructure assets.

WWF China selected the recently reclaimed polder Xipanshanzou, a village in Yuanjiang County, Hunan Province, in the Dongting Lake area, to start realizing the above goals. After the 1998 flood, the national government decided to give up the Xipanshanzhou polder, which opened the way for WWF China to start a joint transition process with the local people to alternative land use. The impulses from the national level prompted local governments for actions, and they were willing to go along with the WWF pilot project because it included raising living conditions for the local inhabitants. Starting in 1999, 147 households were selected to participate in the project. First, WWF China organized meetings for the local people, explaining how the natural lake systems function and how human intervention during the previous decades had led to the deterioration of the ecological functioning and increased flood risks. After these "awareness sessions", WWF led a joint exploration of alternative livelihoods that were more in alignment with the natural dynamics of such a huge lake as Dongting. Eventually, a series of workshops produced support for several alternative income generating activities, including animal husbandry (pig, duck, cow, hen, and goat), fish cage farming, and organic horticulture (moving away from growing rice). Biogas as an alternative source of energy was also introduced, and a number of households living in the polder were resettled to higher grounds.
The approach created public support for the new way of life, but one result that particularly boosted motivation was an increase in the participants' annual income by more than $100 \%$. In 2000 , income attributable to the project was $1465 \mathrm{RMB} /$ household; in 2003, it had reached $2881 \mathrm{RMB} /$ household, and in 2004, the figure was $3196 \mathrm{RMB} /$ household. A WWF survey (Schuyt 2005) demonstrated that households participating in the project had a higher income level than nonparticipants. The average household income of polder residents totaled $9360 \mathrm{RMB} /$ household in 2003 (up from 2000 RMB/household in 1999). In addition to an increase in income, the project generated important living standard improvements. These produced a ripple effect: without any intervention by the Dongting Lake project, neighboring families replicated activities like pig farming and cooking on biogas stoves. The project demonstrated active participation by and benefits for women and the elderly. Another major outcome came in the form of raised awareness among the local community about the importance of their environment (Schuyt 2005). Overall, the livelihoods approach used by the WWF project at Dongting Lake produced lasting improvements seen beyond the end of funding in 2001.

Various partnerships for livelihood development were built during the project. At the local level, WWF China supported the creation of a community-based organization, in which 110 families participated, and an Organic Farming Association managed by farmers and headed by the local village leader. Organic agriculture companies (among others, the Hunan Sun and Soil Organic Agriculture Company and the Naniwan Agriculture Company) also became involved during the exploration and building of a solid market for the products of organic farming and horticulture. This public-private co-operation provided support and marketing advice to farmers and the Organic Farming Association. The MEP's Organic Development Center certified some of the organic products, thereby giving them official endorsement.

Apart from joint efforts with WWF China in the Dongting Lake project to search for and develop alternative livelihoods, actions were taken to restore the ecological value of the Xipanshanzhou polder. Success in identifying sufficient alternative livelihoods led to relocation of the residents of the polder and wetland restoration of its entire acreage, a total embanked area of 110 hectares. At present, 
the former polder also serves as a flood retention area during high peak flows on the Yangtze, when it can be inundated to reduce the floodwater level (WWF China 2009). Preliminary biodiversity monitoring reports from WWF China showed vegetation species diversity and quantity both increased, bringing an increase also in amphibian, fish, and bird species (WWF China 2009). As a result of the wetland restoration, major environmental and heavy metal indices for water (including dissolved oxygen, nitric salt, ammoniasalt, coliform, microbe population, and fluorine) were lower than those set in health standards for water used to irrigate food crops (Schuyt 2005).

In summary, the WWF Dongting Lake project demonstrates that a bottom-up approach that uses the expertise of local farmers makes it possible to identify and adopt alternative livelihoods that are better suited to the natural environment and are conducive to its restoration. Both results are important aspects of IRBM.

The role of the Integrated River Basin Management Task Force of the China Council for International Cooperation on Environment and Development

Active involvement of the other major water resource management institutions became more pressing during the Dongting demonstration project. Possibly one of the most difficult and important steps was to bring the CWRC and the MWR into the process. A perfect opportunity occurred when the CCICED decided to devote a special task force to IRBM implementation in China. The Chinese government had established the CCICED in 1992 as a high-level non-governmental advisory organization with the aim "to further strengthen cooperation and exchange between China and the international community in the field of environment and development" (CCICED 2009).

For the past several years, the CCICED has been successful in providing high-level advice and helping Chinese decision-makers better understand the relationship between environmental protection and economic development in the river basin context.

The CCICED launched the IRBM Task Force in 2002 to advise and inform the national government on implementation of IRBM in China. At that time the CCICED's WWF representative had succeeded in gaining a chair position. This made it possible to promote two candidates who had a clear view of IRBM and the importance of a healthy river ecosystem to co-chair the IRBM Task Force. The viewpoints of the co-chairs are important because they set the agenda for the task force and thus pave the way for recommendations to the Chinese government. WWF China was also pleased to cohost the task force secretariat as a way to further ground its position.

The co-chairs of the IRBM Task Force delivered their recommendations to the CCICED Annual General Meeting in November 2004. The recommendations went on to the relevant ministries (in particular MWR) for implementation. In 2006, the CWRC began revisions (expected to take three years) to the Yangtze Basin Comprehensive Utilization and Development Plan to make it more sustainable and integrated. Although this was not a direct result of CCICED recommendations, it shows how a new way of thinking has taken hold to some degree in the Chinese government. Even more important was acceptance of the recommendation to establish a special Yangtze Forum, which would gather all key stakeholders of the river basin (Yangtze Forum 2009).

The Yangtze Forum was established as a precursor to an Integrated Yangtze River Basin Commission and is responsible for developing a vision for the river's management and for coordination of the activities of the national and provincial government. Its membership established a multi-disciplinary team that included scientists, NGOs, and representatives from all the major water management institutions.

It is important to note that the work of CCICED's IRBM Task Force directly facilitated the local interactions between CWRC and WWF China in the Dongting Lake case. In this way, WWF China was able to demonstrate that there are good alternatives to the mainstream water management approaches used previously. It also increased the credibility and trustworthiness of WWF China as a partner. The success of the Dongting Lake project has received a lot of public attention from all kinds of media. Site visits, an international conference, and publications have also created visibility and impact. The project's positive results and reception opened the door for other projects. 
The WWF-HSBC Yangtze Programme - restoring the web of life

The WWF-HSBC Yangtze Programme is a major freshwater initiative to restore the "web of life" along the Yangtze River by reconnecting lakes to the river's main flow. The reconnection program, part of the five-year eco-partnership between WWF and HSBC (Hongkong Shanghai Banking Corporation, one of the original banks merged and rebranded), started in 2002. The goal was to rehabilitate the food chain and ecological networks in the Central Yangtze River basin through policy work and demonstration projects that undertake reconnection, support local economic development, and create a network of wetland reserves. The Zhangdu Lake, Hong Lake, and the Tian-e-zhou Oxbow in Hubei were selected as demonstration sites.

More than 100 lakes once dotted the Yangtze River basin and natural channels linked the river's main tributaries. Even at its current reduced level, this network of interwoven streams and lakes creates a unique and complex ecosystem that is rich in biodiversity, but middle and lower reaches of rivers are often the sites of heavy rainfall and extensive flooding. Farmers who work the rice paddies are at risk from snail fever (schistosomiasis), an infection that leads to gradual, serious damage to the internal organs. Snail fever is caused by a blood fluke (a trematode), which grows in lakes and rivers and swims into the paddies (Wu et al. 2008). To prevent flooding and stop blood flukes from reaching rice paddies, dams and thousands of kilometers of dykes were built in the basin beginning in the 1950s (Utzinger et al. 2005). The dams and dykes often cut off water flow between rivers and lakes. Few considered the impact of this disconnection on water quality, fish migration routes, flora, and fauna. It obstructed the natural flow of migratory fish, dramatically decreasing biodiversity across the whole basin (Fu et al. 2003, Park et al. 2003, Wu et al. 2004, Lopez-Pujol et al. 2006, Yang et al. 2007). Inbreeding among the fish led to inferior quality specimens of much smaller size. In addition, the number of fish species decreased considerably from 74 to 57 in Hong Lake from the 1960s to the 1990s, and from 80 to 52 in Zhangdu Lake from the 1950s to the 2000s (Wang et al. 2005, Fang et al. 2006) .

Within a few years, the locals' lucrative fishing business seemed on its last legs. Still, though, resource destruction continued as intensive land reclamation followed the construction of the dykes, with both agricultural and urban settlements springing up on the former flood plains and around the lakes. In the 1990s, Zhangdu Lake dwindled to about one quarter of its original size in the 1930s (Wang et al. 2005, WWF personal communication). Lakes also began to suffer from the inflow of farm runoff and domestic and industrial sewage. Deteriorating water quality affected local ecology and wildlife. Natural fisheries output in the two lake regions declined sharply. Without the natural water exchange with the river, the lakes quickly started to clog with silt. For example, the annual deposit of silt in Zhangdu Lake increased from an average depth of just one centimeter to one meter after it was disconnected from the Yangtze in the 1950s. All these effects continue today.

Within the framework of the WWF-HSBC project, environmental experts propose seasonal opening of the dykes (outside flood season) to help restore the lakes' natural links to the Yangtze. The opening coincides with the fish breeding season to enable the migratory flow, allowing fish to breed upstream in the Yangtze and fish fry to return to the lake where they mature. This measure will also ensure a natural hydrological fluctuation in the lakes, where wetland areas will receive fresh water from the Yangtze, helping to ensure a healthy wetland ecosystem. To prevent the re-entry of blood flukes during the linking period, the local governments now provide funds to build concrete snail retention ponds between the first and second sluice gates linking river and lake. Involving all the relevant sectors of local government has been, and still is, an important way to gain their commitment. This receives a lot of attention from WWF (WWF, personal communication).

The program staff have also been promoting the concept of environment-friendly farms and fisheries in the reconnection scheme, hoping to restore wetland habitats for displaced migratory and endemic birds, as well as to reduce water pollution. Local fish farmers have been using fertilizer for a few years to promote the growth of algae, which serves as food for fish, but poisonous substances in the fertilizer sink into the silt and accumulate. As a result, epidemics among fish have become increasingly frequent. Local fishermen were invited to join an eco-fishery program that was advocated by the local government and WWF China. Farming became a more environment-friendly type that 
Fig. 4. Yangtze River and Zhangdu Lake, Hong Lake, and Tian-e-zhou Oxbow.

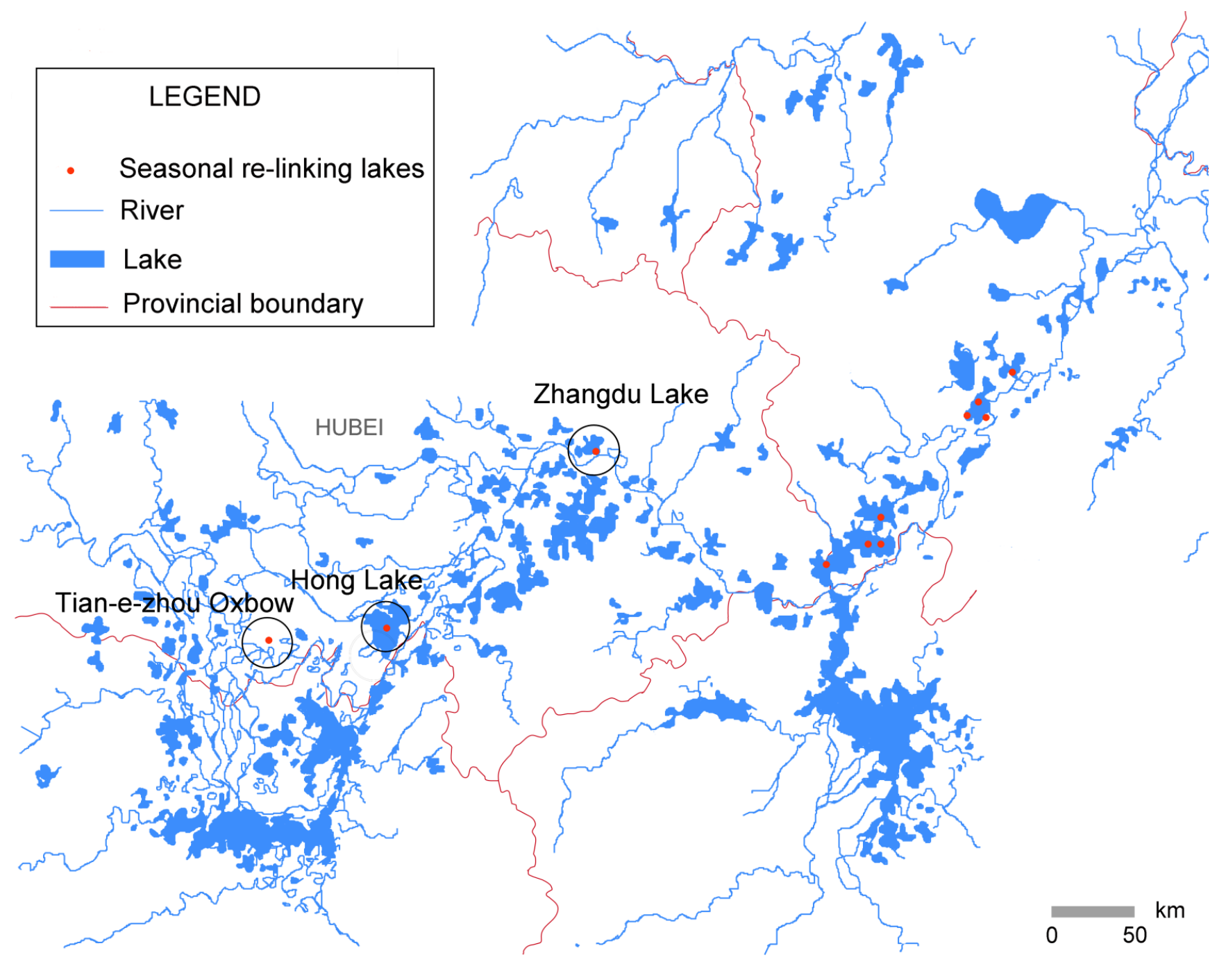

demands clean aquatic conditions and uses a special fish species that feeds on artificial fish pellets. Fish farmers who have put the eco-fishery program into practice are currently earning more than two to three times the sums that are typical of traditional farming practices (WWF China 2009, WWF China, personal communication).

The Yangtze program has so far resulted in the seasonal re-linkage of 11 lakes to the Yangtze River. The wetlands covering 450,000 hectares are effectively protected. Water quality has improved, and 34 varieties of birds and 14 species of fish now travel freely back to the river. In all, 15 million bamboo poles and fishing nets have been removed, and the "falling and rising tide of the Hong Lake" has returned. In addition, members of 296 families have been taught sustainable fishing solutions, which has helped increase their incomes by more than $20 \%$. 


\section{ANALYSIS}

It can be argued that the idea of a strong state or nation state in which government has more sway than governance in many ways still applies to the Chinese political situation. Obviously, government takes the leading role, especially in water management. This in itself, and in relation to the institutionalization of water resource management, might not actually be much different than in other, more democratically governed countries. However, it can be argued that in western (democratic) culture, a cause must become a social movement or at least a social issue before it can become part of a political agenda. There is a vast body of knowledge on the extent of these movements, the capacity to actually change policy, and the different ways in which agenda setting and policy influence can and does occur (see Huitema and Meijerink 2010). In China, agenda setting is limited mainly to the central government as the country's leader of innovation. This means that policy making in China is much less of a "multi-level game" than in western nations. However, clearly, Chinese society and the way it is governed are changing, opening avenues for third parties to enter the game, albeit with caution and care. The projects examined show WWF China is successfully following new political paths in China in just such a way.

WWF China plays the role of main policy entrepreneur in our case studies. Since the start of China's Open and Reform Policy in 1978, WWF has been active in the country (launching a panda protection project in 1980). WWF, an international NGO, currently has a subdivision in China but still no status as a Chinese NGO, although this may change in the coming years. A lot of time has been required for it to be able to address environmental issues in China and cooperate successfully with governmental bodies in finding a better balance between nature and the economy. One of the major characteristics of policy entrepreneurship in China seems to be perseverance. Over the years, WWF has slowly built a coalition with the Chinese Academy of Sciences and the State Forestry Administration. Resulting cooperation led to nature reserve staff training in the 1980s and to some Ramsar site listings as early as 1992, but it was not until the 1998 flood and the proclamation of the 32 character policy that a problem window was created that gave WWF China the opportunity to bring a new perspective on sustainable river basin management to the table. In this context, WWF China was able to launch its Living River program and organize joint planning events with local farmers, regional authorities, and water management experts to identify alternative livelihoods (Case I, Dongting Lake), restore wetlands, and implement sustainable fishing programs (Case II, Hong Lake).

The introduction and implementation of new ideas generates a broad spectrum of technical and nontechnical questions and often requires seed money to trigger transition processes. In water management and land use, therefore, the need to make optimal use of available knowledge, experience, and finances makes it essential to build coalitions with public, private, and governmental stakeholders in the river basin. This is true at both the national and international level. The successful creation of coalitions led to the discovery of the experts and funding necessary to launch the Living River program and its demonstration projects.

However, in any society, working from the bottom up to generate policy change is not sufficient. Particularly in a country like China, where agenda setting for innovation is usually centralized, it is very important to invest time and attention in enlisting administration officials, lawmakers, policy research specialists, and journalists. For this reason, WWF China worked with the CCICED once it became clear that this organization would formulate recommendations to implement IRBM in China. This investment proved highly profitable. By providing the secretariat of the IRBM Task Force and by lobbying for suitable co-chairs, WWF provided a firm basis for incorporating the approach into the final CCICED recommendations with an effective plan for implementation, including, for example, establishment of the Yangtze Forum. WWF China's strategic cooperation also helped expedite the administrative process, resulting, for instance, in the recommendations being delivered directly to the premier of the State Council without passing through the ministerial levels.

Parallel to this activity, intensive contact with the academic field (e.g., the Chinese Academy of Sciences) opened the way to media coverage in the form of a special issue in the National Chinese Geographic, articles in the China Daily newspaper, and newsletters for experts dealing with IRBM. This had a huge impact on awareness within and outside of China. Now, following the demonstration projects, the transition to IRBM seems to be gaining momentum and meeting little coordinated effort to block forward movement. 
That said, the context for the transition process needs to be considered. The introduction and implementation of IRBM as a new paradigm can be regarded as the emergence of resistance to the Chinese hydrological mission and its unintended consequences. However, the ongoing execution of large hydro-engineering projects indicates a competition between two paradigms and an outcome that has still to be determined (Boxer 2001, McCormack 2001). As seen, too, in other countries, the difference between policy transition and policy implementation will also be telling.

The adoption of IRBM in China necessarily involves the Chinese political system and consequently its governance system. In this respect, we refer to the trialogue model currently refined by Turton et al. (2007), in which governance and especially good governance (as a product) depends on a dynamic interplay between the domains of government, society, and science. This model underlines the importance of stakeholder participation, accountability, and ultimately democracy in order to achieve good governance. The concept of IRBM (and the related concept of Integrated Water Resources Management) is based on the same principles regarding the "human system" as formulated by the Global Water Partnership (Global Water Partnership (GWP) 2000, Jonch-Clausen and Fugl 2001, Falkenmark et al. 2004). It requires a major participatory role for all stakeholders involved and appears to root firmly in a democratic policy system. As such, IRBM as developed elsewhere might not be fully applicable to the Chinese situation.

As shown, however, the Chinese government has allowed room for a new paradigm to enter. The rules of stakeholder participation may differ, but, as cautiously undertaken in the cases presented above, efforts are being made to involve stakeholders in parts of the policy cycle (Wang et al. 2003, Zhong and Mol 2007). How the government will attempt to direct the transition to IRBM and the results, both in water management and in governance, will be of great interest for future study.

\section{Strategies of transition management}

In order to characterize the strategies used by WWF China as a policy entrepreneur, we use the terminology and categorization presented in Huitema and Meijerink (2010).

\section{Development of new ideas}

WWF China introduced ideas that were new to Chinese decision makers. The importance of wetlands and the possibility of using them as flood retention areas while simultaneously restoring valuable ecosystems was a novelty previously discussed only in academic settings in China. The concept of IRBM as an approach where the environment, safety, and economic matters can go hand in hand (Case I, Living River program) was likely the most influential "new" idea. The IRBM conceptual framework provided a basis for rethinking all kinds of engineering solutions and methods that exploit freshwater resources and cause detrimental effects to ecosystem functions.

\section{Build coalitions and sell ideas}

Coalition building is a very important part of WWF's strategy and thus also of WWF China. It is a core WWF belief that "no solution will be effective in any river basin unless it is implemented through cooperation across social, economic, and political boundaries" (Jones et al. 2003). All stakeholders in a river basin need to come together around the table, establish respect for each other, number the needed experts among themselves, and bring the financing necessary to identify solutions in which the environmental, safety, and economic goals are well balanced. Generally, this method of working prevents unfair distribution of effort and costs where only one or two groups of stakeholders would have to "bear the pain".

Involvement of the wider public in the transition process takes the formulation of clear messages in plain language that are illustrated with practical examples of where the "new" ideas have proven to be feasible, easily adopted, and expanded and improved by other stakeholders. These messages need to be made available prior to or during public events that re designed to draw media attention. WWF China accomplished all these steps very effectively in both the Yangtze River basin cases studied.

\section{Recognize and exploit windows of opportunity}

That WWF China acted during the right window of opportunity is clear. It did so by first presenting plans already formulated for the Yangtze River basin and Dongting Lake in concordance with and building upon the national 32 character policy. 
Next, to ensure top-level influence, it capitalized on WWF representation on the CCICED and support for IRBM by other members in order to steer the related task force and hence to influence national policy makers.

Only once it was part of the senior hierarchy of the CCICED could WWF create a shadow network, a circle outside of direct governmental influence, where there was more room for debate. This network has proven to be very influential in the introduction of IRBM and in bypassing less enthusiastic organizations and players.

Recognize, exploit, create, and/or manipulate the multiple venues in modern societies

Many venues exist for policy issue debate. These include, for example, various government processes, from planning to legislative and science fora. As Richardson (2000) argues, these venues are an interest group resource, that is, they can be exploited by policy entrepreneurs.

In the context of introducing IRBM to China, WWF China has also demonstrated a capacity to recognize and make efficient use of international and national venues that are known and visible in society. One of the most important parts of the WWF strategy is its constant advocacy of its ideas, successes, approaches, and visions for the future. Clearly, use of both international and national media is very important, but informing politicians at all levels of government through field visits, conferences, lectures and so on, might be just as important. The success of the IRBM Task Force and the amount of positive media coverage of its demonstration projects show that WWF China can be considered a very effective "venue shopper" (Richardson 2000).

\section{Orchestrate and manage networks}

Upscaling ideas and implementing new policies entails expanding and managing networks at all levels in society. Mustering sufficient public support and the necessary "entrepreneurship" to envision, draft, and implement new policies and/or concepts demands more than one social actor. WWF sets out, therefore, to finance demonstration projects but is keen to return ownership to the appropriate level of governance or society, including financial ownership for scaling up the demonstration projects and converting innovation to common practice. This explains why, apart from realizing demonstration projects, WWF's core business is the orchestration and management of networks worldwide. These networks are managed by individuals who are highly skilled at addressing stakeholders of all kinds with respect and at communicating solutionoriented strategies.

\section{LESSONS LEARNED AND CONCLUSIONS}

In this paper we have elaborated the role of WWF China as a change agent for the transition process to IRBM in China. We have demonstrated that WWF uses various strategies of different types to support this transition process. Successful deployment of these strategies for change in environmental policy requires special skills, actions, and attitudes on the part of the policy entrepreneur (the role taken by WWF China in the cases presented above), including:

1. Broad focus: efforts are needed to understand the interests of partner stakeholders. For WWF China, this means a focus not only on biodiversity but also on the importance of a healthy ecosystem in balance with sustainable livelihoods and economies.

2. Pursuit of win-win situations that respect the interests of all stakeholders: what do they seek to gain or lose from the ultimate goal, and where do they stand regarding the balance of economy, safety, and ecology?

3. Focus on the realization of demonstration projects: one successful demonstration project proved more convincing than any number of reports and academic studies.

4. Support for and action on a transition process by players at all societal levels: this requires investment by a change agent in a joint planning process run from the bottom up and from the top down.

5. Use of media as powerful tools for dissemination: messages need to be linked to news events.

6. Attention to the continuation of demonstration projects: help-desks and/or other forms of support need to be organized to assist stakeholders as they take over the lead in the transition process. 
7. Frequent, continuous, and meaningful communication: reiteration of long-term goals and presentation and analysis of shortterm successes proved helpful in the work of WWF China.

WWF as an IRBM policy entrepreneur contributed considerably to China's current stance on river basin management to the point where hardly any official now defends the traditional development model of high levels of growth and high pollution. According to the China Daily newspaper, officials of Shanxi, Henan, and some other resource rich provinces planned to close down local small coal mines and chemical plants managed on $19^{\text {th }}$ century concepts, even though they were erected only a decade or so earlier (You 2007). Specifically in regard to the water sector, the China Daily mentioned that Hunan Province recently closed down 230 paperproducing plants, resulting in an improvement of water quality from level V to level III (near drinking water standard) within two months ( $\mathrm{Xu}$ 2007). Although the newspaper is a state medium and as such gives voice to the official view, these kinds of reports are a sign that those who govern China recognize the growing importance of environmental issues. This represents a continuing opportunity for skilled, strategic action by policy entrepreneurs who are seeking transitions to ecologically and economically sustainable policies in China.

Responses to this article can be read online at: http://www.ecologyandsociety.org/voll5/iss2/art23/ responses/

\section{Acknowledgments:}

We thank Edward Elgar Publishing who have kindly given permission for the use of material from Huitema. D., and S. Meijerink, editors. 2009. Water policy entrepreneurs: a research companion to water transitions around the globe. Cheltenham, $U K$. We thank the anonymous reviewers for their valuable comments and suggestions.

\section{LITERATURE CITED}

Boxer, B. 2001. Contradictions and challenges in China's water policy development. Water International 26(3):335-341.

Changjiang Water Resources Commission (CWRC). [online] URL: http://www.cjh.com.cn/eng/ index.html and www.cjw.com.cn/eng/eng-about.asp . Accessed 25 August 2009.

Chen, Z. 2005. Tackling China's water pollution problem: a legal and institutional perspective from Taihu Lake water pollution control. Temple Journal of Science, Technology and Environmental Law 24:325-350.

China Council for International Cooperation on Environment and Development (CCICED). [online] URL: http://www.cciced.net/encciced/. Accessed 25 August 2009.

China Council for International Cooperation on Environment and Developmentand World Wildlife Fund for Nature (CCICED and WWF). 2004. Promoting integrated river basin management and restoring China's living rivers. CCICED Task Force on Integrated River Basin Management, Beijing, P. R. China.

Costanza, R., R. dArge, R. de Groot, S. Farber, M. Grasso, B. Hannon, K. Limburg, S. Naeem, R. V. Oneill, J. Paruelo, R. G. Raskin, P. Sutton, and M. van den Belt. 1997. The value of the world's ecosystem services and natural capital. Nature $\mathbf{3 8 7}$ (6630):253-260.

Cui, L. J., and Y. F. Wang. 2008. Wetlands of international importance of China. China Forestry Press, Beijing, P. R. China, in Chinese.

Falkenmark, M., L. Gottschalk, J. Lundqvist, and P. Wouters. 2004. Towards integrated catchment management: increasing the dialogue between scientists, policy-makers and stakeholders. International Journal of Water Resources Development 20(3):297-309.

Fang, J., Z. H. Wang, S. Zhao, Y. Li, Z. Tang, D. Yu, L. Ni, H. Liu, P. Xie, L. Da, Z. Li, and C. Zheng. 2006. Biodiversity changes in the lakes of the Central Yangtze. Frontiers in Ecology and the Environment 4(7):369-377. 
Fischer, G., and G. K. Heilig. 1997. Population momentum and the demand on land and water resources. Philosophical Transactions of the Royal Society of London Series B-Biological Sciences $\mathbf{3 5 2}$ (1356):869-888.

Flavin, C., and G. Gardner. 2006. China, India, and the New World Order. Pages 3-23 in L. Starke editor. State of the world 2006. Worldwatch Institute, Washington D.C., USA.

Fu, C. Z., J. H. Wu, J. K. Chen, Q. H. Qu, and G. C. Lei. 2003. Freshwater fish biodiversity in the Yangtze River basin of China: patterns, threats and conservation. Biodiversity and Conservation 12 (8):1649-1685.

Global Water Partnership (GWP). 2000. Integrated Water Resources Management. TAC Background Papers, GWP, Stockholm, Sweden.

Huitema, D., and S. Meijerink. 2010. Realizing water transitions. the role of policy entrepreneurs in water policy change. Ecology and Society 15(2): 26. [online] URL: http://www.ecologyandsociety.org/vol15/ iss2/art26/.

Hunan Province. [online] URL: http://www.hbj.hu nan.gov.cn (in Chinese) and www.hbj.hunan.gov.cn/ dongT1/wzDisplay.aspx?id=130. Accessed 25 August 2009.

Jonch-Clausen, T., and J. Fugl. 2001. Firming up the conceptual basis of integrated water resources management. International Journal of Water Resources Development 17(4):501-510.

Jones, T., B. Phillips, C. Williams, and J. Pittock, editors. 2003. Managing rivers wisely - lessons from WWF work for integrated river basin management. WWF International, Gland, Switzerland.

Kreimer, A., and M. Munasinghe. 1991. Managing environmental degradation and natural disasters: an overview. Pages 3-6 in A. Kreimer and M. Munasinghe, editors. Managing natural disasters and the environment. World Bank, Washington D.C., USA.

Lee, S. 2006. China's water policy challenges. China Policy Institute Discussion Paper 13. China Policy Institute of the University of Nottingham, Nottingham, UK. [online] URL: http://www.nottin gham.ac.uk/shared/shared cpi/documents/ discussion papers/Discussion Paper 13 China W ater Policy Challenges.pdf.

Li, Y. S., A. C. Sleigh, A. G. P. Ross, G. M. Williams, and M. Tanner. 2000. Epidemiology of Schistosoma japonicum in China: morbidity and strategies for control in the Dongting Lake region. International Journal for Parasitology 30(3):273281.

Lopez-Pujol, J., F. M. Zhang, and S. Ge. 2006. Plant biodiversity in China: richly varied, endangered, and in need of conservation. Biodiversity and Conservation 15(12):3983-4026.

McCormack, G. 2001. Water margins - competing paradigms in China. Critical Asian Studies 33(1):530 .

Ministry of Environmental Protection (MEP). Report on the state of the environment in China 2007. [online] URL: http://english.mep.gov.cn/sta ndards reports/soe/soe2007/200909/t20090922_161251. $\underline{\mathrm{htm}}$. Accessed 21 November 2009.

Ministry of Water Resources of the People's Republic of China (MWR). [online] URL: http:// wWW.mwr.gov.cn/english/. Accessed 25 August 2009.

Muldavin, J. 2000. The paradoxes of environmental policy and resource management in reform-era China. Economic Geography 76(3):244-271.

Nakamura, T. 2003. Ecosystem-based river basin management: its approach and policy-level application. Hydrological Processes 17:27112725.

Nakamura, T. 2006. Development of decision making indicators for ecosystem-based river management. Hydrological Processes 20:12931308.

Organisation for Economic Co-operation and Development (OECD). 2007. OECD environmental performance reviews: China 2007. OECD Publishing, Paris, France.

Olson, D. M., and E. Dinerstein. 1998. The global 200: a representation approach to conserving the Earth's most biologically valuable ecoregions. Conservation Biology 12(3):502-515. 
Park, Y. S., J. B. Chang, S. Lek, W. X. Cao, and S. Brosse. 2003. Conservation strategies for endemic fish species threatened by the Three Gorges Dam. Conservation Biology 17(6):17481758 .

Ramsar Convention on Wetlands (Secretariat). [online] URL: www.ramsar.org. Accessed 25 August 2009.

Richardson, J. 2000. Government, interest groups and policy change. Political Studies 48(5):10061025 .

Schuyt, K. 2005. Freshwater and poverty reduction: serving people, saving nature. World Wide Fund for Nature - International, Zeist, the Netherlands.

Schuyt, K., and L. Brander. 2004. The economic values of the world's wetlands, living waters. WWF International and Institute for Environmental Studies, Vrije Universiteit Amsterdam, Gland/ Amsterdam, Switzerland/the Netherlands.

Turner, J. L., and K. Otsuka. 2005. Promoting sustainable river basin governance: crafting JapanU.S. water partnerships in China. Pages 5-19 in J. L. Turner and K. Otsuka, editors. Promoting sustainable river basin governance - crafting Japan-U.S. water partnerships in China. IDE JETRO Spot Survey 28, Institute of Developing Economies, Chiba, Japan. [online] URL:http://www .ide.go.jp/English/Publish/Download/Spot/28.html

Turner, J. L., and K. Otsuka. 2006. Reaching across the water. Woodrow Wilson International Center for Scholars, Washington D.C., USA. [online] URL: http://www.wilsoncenter.org/topics/ pubs/WWC ENG Composite.pdf.

Turton, A. R., H. J. Hattingh, G. A. Maree, M. Claassen, P. J. Roux, and W. F. Strijdom. 2007. Governance as a trialogue: government-societyscience in transition. Springer-Verlag, Berlin/ Heidelberg, Germany.

Utzinger, J., X. N. Zhou, M. G. Chen, and R. Bergquist. 2005. Conquering schistosomiasis in China: the long march. Acta Tropica 96(2-3):69-96.

Varis, O., and P. Vakkilainen. 2001. China's 8 challenges to water resources management in the first quarter of the 21st century. Geomorphology 41:93-104.

Wang, L., H. Hu, and D. Wang. 2005. Ecological impacts of disconnection from the Yangtze on fish resources in Zhangdu Lake. Resources and Environment in the Yangzte Basin 14(3):287-292. In Chinese.

Wang, Q. G., G. Gu, and Y. Higano. 2006. Toward integrated environmental management for challenges in water environmental protection of Lake Taihu basin in China. Environmental Management 37 (5):579-588.

Wang, Y., L. Li, X. J. Wang, X. B. Yu, and Y. H. Wang. 2007. Taking stock of integrated river basin management in China. WWF China, Beijing, P. R. China.

Wang, Y., R. K. Morgan, and M. Cashmore. 2003. Environmental impact assessment of projects in the People's Republic of China: new law, old problems. Environmental Impact Assessment Review 23:543579.

Waterbury, J. 1979. Hydropolitics of the Nile Valley. Syracuse University Press, Syracuse, New York, USA.

World Bank. 1997. Clear water and blue skies: China's environment in the new century. World Bank, Washington D.C., USA.

World Wildlife Fund for Nature (WWF) China. [online] URL: http://www.wwfchina.org/english/index. shtm. Accessed 25 August 2009.

World Wildlife Fund for Nature (WWF) International. [online] URL: http://www.panda.org . Accessed 25 August 2009.

Wu, J. G., J. H. Huang, X. G. Han, Z. Q. Xie, and X. M. Gao. 2004. The Three Gorges Dam: an ecological perspective. Frontiers in Ecology and the Environment 2(5):241-248.

Wu, X. H., S. Q. Zhang, X. J. Xu, Y. X. Huang, P. Steinmann, J. Utzinger, T. P. Wang, J. Xu, J. Zheng, and X. N. Zhou. 2008. Effect of floods on the transmission of schistosomiasis in the Yangtze River valley, People's Republic of China. Parasitology International 57(3):271-276. 
Xu, X. 2007. Hunan Province cleans up its act. Page 24 in China Daily. 17 October 2007. [online] URL: http://www.chinadaily.com.cn/cndy/2007-10/17/ content 6181797.htm.

Yan, F., D. He, and B. Kinne. 2006. Water resources administration institution in China. Water Policy 8:291-301.

Yang, G. S., L. D. Weng, and L. F. Li. 2007. Yangtze conservation and development report. Wuhan, P. R. China.

Yang, H., and J. B. Zehnder. 2005. The south-north water transfer project in China. Water International 30(3):339-349.

Yangtze Forum. [online] URL: http://www.yangtz eforum.org/forum-eng.asp. Accessed 25 August 2009.

Yin, H., and C. Li. 2001. Human impact on floods and flood disasters on the Yangtze River. Geomorphology 41(2-3):105-109.

Yin, H., G. Liu, J. Pi, G. Chen, and C. Li. 2006. On the river-lake relationship of the middle Yangtze reaches. Geomorphology 85:197-207.

You, J. M. 2007. Transforming the model. Page 5 in China Daily. 15 October 2007. [online] URL: http://www.chinadaily.com.cn/bw/2007-10/15/ content 6173701.htm.

Zhao, S., and J. Fang. 2004. Impact of impoldering and lake restoration on land-cover changes in Dongting Lake area Central Yangtze. Ambio 33 (6):311-315.

Zhao, S., J. Fang, W. Ji, and Z. Tang. 2003. Lake restoration from impoldering: impact of land conversion on riparian landscape in Honghu Lake area, Central Yangtze. Agriculture, Ecosystems \& Environment 95(1):111-118.

Zhao, S. Q., J. Y. Fang, S. L. Miao, B. Gu, G. Tao, C. H. Peng, and Z. Y. Tang. 2005. The 7-decade degradation of a large freshwater lake in central Yangtze river, China. Environmental Science \& Technology 39(2):431-436.

Zhao, S., C. Peng, H. Jiang, D. Tian, X. Lei, and X. Zhou. 2006. Land use change in Asia and the ecological consequences. Ecological Research 21 (6):890-896.

Zhong, L. J., and A. P. J. Mol. 2007. Participatory environmental governance in China: public hearings on urban water tariff setting. Journal of Environmental Management 88(4): 899-913. 